\title{
Technology Acceptance Model' Concepts, Contribution, Limitation, and Adoption in Education
}

\author{
Samar Zaineldeen ${ }^{1, *}$, Li Hongbo ${ }^{1}$, Aka Lucien Koffi ${ }^{1}$, Bilal Mohammed Abdallah Hassan ${ }^{2}$ \\ ${ }^{1}$ School of Management, Jiangsu University, Jiangsu, China \\ ${ }^{2}$ School of Economics and Management, Being Forestry University, China
}

Received June 10, 2020; Revised September 1, 2020; Accepted September 11, 2020

\begin{abstract}
Cite This Paper in the following Citation Styles
(a): [1] Samar Zaineldeen, Li Hongbo, Aka Lucien Koffi, Bilal Mohammed Abdallah Hassan, "Technology Acceptance Model' Concepts, Contribution, Limitation, and Adoption in Education," Universal Journal of Educational Research, Vol. 8, No. 11, pp. 5061-5071, 2020. DOI: 10.13189/ujer.2020.081106.
\end{abstract}

(b): Samar Zaineldeen, Li Hongbo, Aka Lucien Koffi, Bilal Mohammed Abdallah Hassan (2020). Technology Acceptance Model' Concepts, Contribution, Limitation, and Adoption in Education. Universal Journal of Educational Research, 8(11), 5061-5071. DOI: 10.13189/ujer.2020.081106.

Copyright $\odot 2020$ by authors, all rights reserved. Authors agree that this article remains permanently open access under the terms of the Creative Commons Attribution License 4.0 International License

\begin{abstract}
Numerous models have been provided by researchers in the past to determine and assess the success of Information Systems. Every model has been evaluated. Consequently, each model has pros and cons related to it. Here we are studying the Technology acceptance Models (TAM) and debating their features, contributions, and the limits of the earlier version of this theory. The TAM model, created by Davis (1989), is applied to determine the acceptance, adoption, and utilization of information technology. It is prevalent two constructs are used in TAM, perceived ease of use and perceived usefulness. The TAM model gained extensive popularity between the researchers, and it is among the most effective models. TAM is dissimilar to other models as it does not measure success. However, it is employed to investigate and predict the users' intention to use Information technology. Since technology acceptance in an academic environment is becoming well-known, what had resulted in hubs of learning describes as an online learning community. Therefore, this paper gives a review of the present state of research on the Technology Acceptance Model. It offers a concise entry point to the theory's background and its adoption in education, which might be purposely advantageous for novice readers. The knowing of these models allows us to know the factors that impact the adoption of IS in the education environment to take advantage of this tool.
\end{abstract}

Keywords Technology Acceptance Model, Education, E-learning

\section{Introduction}

With the massive development of innovation, individuals have a higher chance of utilizing novel technology in their everyday life and work. Indeed, researchers investigated and published a hypothetical model to clarify user's information technology acceptance and use, for example, the theory of reasoned action $[1,2]$, the theory of planned behavior [3,4], as well as the technology acceptance model (TAM) [5,6], and customer adoption of information technology in the direction of a unified view model [7]. Among those speculations and models, "one of a broadly applied models of information technologies acceptance and employ is the TAM" [8]. TAM was applied to clarify the customer acceptance of innovation utilized in a diverse environment setting.

Review in the field of innovation adoption regularly provides a challenge concerning the shortage of comparable studies and consumers' innovation in experience [9]. With the rise in technological reliance in our lives and world economies connection, several researchers linked with the scholarly community and industry have been actively concerned with studying end-user adoption intentions of diverse technologies $[10,11]$.

Regarding education, particularly for electronic learning, in addition to mobile learning, the TAM is enormously functional [12]. It was employed in a study that assessed the recognition of the e-learning platform by learners. 
TAM being assessed incorporates firms [13]; the TAM was employed in research that inspected the attitudes of staff and their adoption of e-learning frameworks in the enterprises.

In the area of administration investigation, TAM has obtained comprehensive experiential support throughout practice, approvals, in addition to applications [14] by practitioners and scholars, proposing that TAM is robust over time, environments, communities, plus technologies. The TAM was utilized in research that examined perceived usefulness along with usage intention regarding impact [15]; this was to assess four longitudinal investigations in administration.

Awareness of the aspect that affects an individual's intent to utilize a system before the design of the system is essential to make the system broadly used and received by potential users. In the field of IS, acceptance research is often conducted to figure out consumer intentions, which help in increasing system utilization. Thus, acceptance studies the area of education is also compulsory.

\section{The aim of the study}

The point of this study is to explore the technology acceptance model studies in the education area mainly. With this investigation, the aim is to bring forth the existing technology acceptance research pattern in the education area, detect the limitations, and propose an upcoming research path.

This study deals with a vital concern in the TAM. Based on the different versions of this theory, this study tried to analyze researches on technology acceptance in the field of education, in particular online learning.

\section{Technology Acceptance Model}

Following [16], the TAM is a model that emulates how the customer comes to accept and utilize an innovation. The TAM is further created for indicating end-user recognition of IS [5]. The conceptual basis for TAM is founded on the theory of reasoned action (TRA) [2]. It was created by [5]. TAM substitutes several of TRA's attitude variables with the two technology acceptance factorsperceived ease of use along with perceived usefulness. TAM concentrates on the approach explanations of intention to apply a particular service or technology. The TAM model has been expanded and customized. Numerous current studies have involved TAM when studying the adoption of online technologies [17].

\subsection{TAM 1}

The TAM was initially established by [18] and further created by Davis et al. [6] to create a model for computer technology acceptance. Surendran [19] verifies that the TAM is one of the concepts that has been base on (TRA) and has been applied to clarify an individual's acceptable behavior. Concurring to [20], TAM substitutes some of TRA's attitude factors with two variables of technology acceptance (perceived ease of use as well as perceived usefulness). It recommends that perceived ease of use as well as perceived usefulness includes an individual's intention to utilize a framework with "intention to use" working as a mediator of framework utilization [21].

Mainly, the TAM is consists of different variables (see Table 1): attitude towards behavior, behavioral intention, actual system use, perceived usefulness as well as perceived ease of use. Figure 1 demonstrates that the actual system usage is instantly affected by behavioral intention, which is impacted by an equal attitude towards behavior and perceived usefulness. Attitude towards behavior is straightly impacted by perceived ease of use in addition to perceived usefulness. The TAM principally relies on two factors, perceived usefulness in addition to perceived ease of use, to inspect persons' beliefs in addition to attitude toward computer technology approval [5]. Perceived Usefulness directly impact by perceived ease of use; also, external factors have an impact on perceived ease of use in addition to Perceived Usefulness.

Table 1. The Constructs of the TAM

\begin{tabular}{|c|c|l|}
\hline Constructs & Literature support & \multicolumn{1}{|c|}{ Definition } \\
\hline Behavioral Intention & {$[22,23,24,25]$} & $\begin{array}{l}\text { An individual intends to act in a manner without guarantees to do so } \\
{[2] .}\end{array}$ \\
\hline Attitude Towards Behaviour & {$[26,27,28,29]$} & $\begin{array}{l}\text { The extent to which a person thinks that acting the behavior is } \\
\text { negative or positive [7]. }\end{array}$ \\
\hline Perceived Usefulness & {$[5,30,31,32]$} & $\begin{array}{l}\text { The extent to which an individual accepts that employing a certain } \\
\text { application framework will raise his or her work performance } \\
\text { inside an organization environment [5]. }\end{array}$ \\
\hline Perceived Ease of Use & {$[30,7,3,5]$} & $\begin{array}{l}\text { Measures the level to which a person assumes that employing a } \\
\text { system is effortless [6]. }\end{array}$ \\
\hline
\end{tabular}




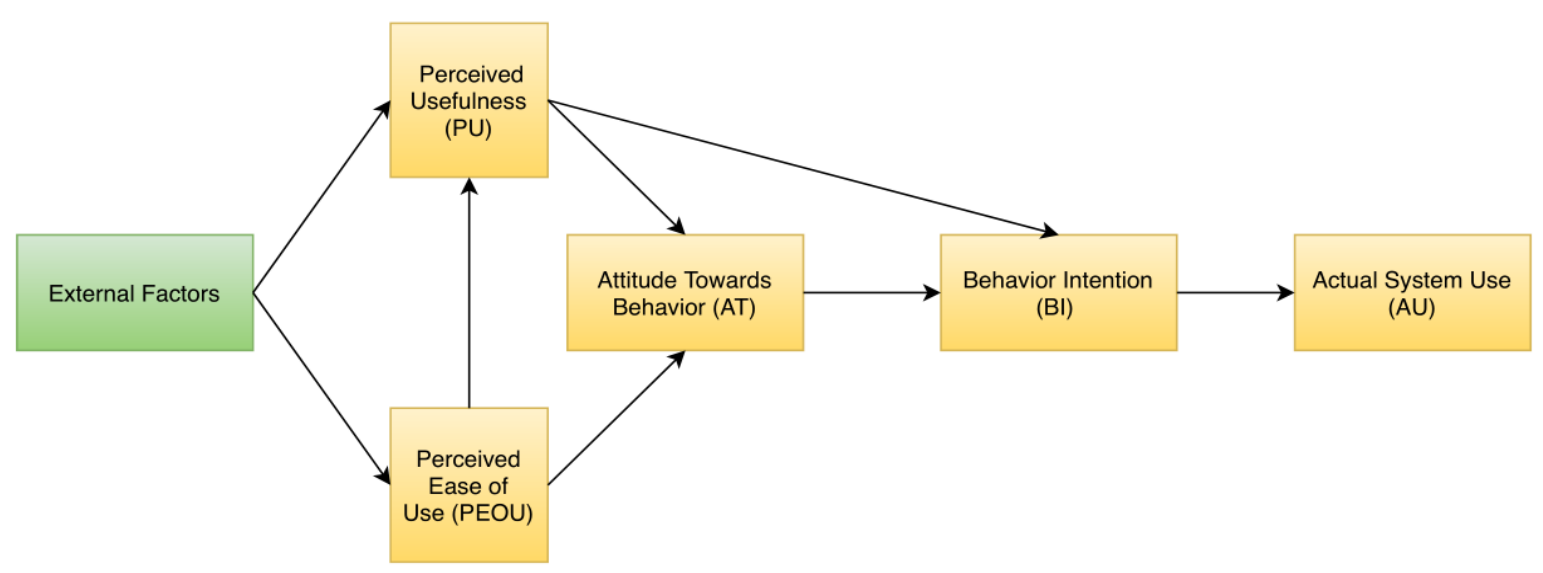

Figure 1. TAM1 Source [5]

Table 2. The Constructs of Perceived Usefulness in the TAM2

\begin{tabular}{|c|c|l|}
\hline $\begin{array}{c}\text { Constructs } \\
\begin{array}{c}\text { Subjective } \\
\text { Norm }\end{array}\end{array}$ & Literature support & \multicolumn{1}{c|}{ Definition } \\
\hline Image & {$[3,29,34,35]$} & $\begin{array}{l}\text { The extent to which a person feels that individuals suppose he or she has to carry out } \\
\text { the behavior [33]. }\end{array}$ \\
\hline Job Relevance & {$[15,35,36,37]$} & $\begin{array}{l}\text { can be characterized as the degree to which one's } \\
\text { status is viewed to be improved by the employ of innovation in one's status of social } \\
\text { systems [35] }\end{array}$ \\
\hline Results Demonstrability & {$[8,35,40,42]$} & The level to which the innovation is correlated to the job of someone [15]. \\
\hline Output Quality & {$[40,41,42,43]$} & Distinct as "what extent the novel technology executes work made by the user" [15]. \\
\hline
\end{tabular}

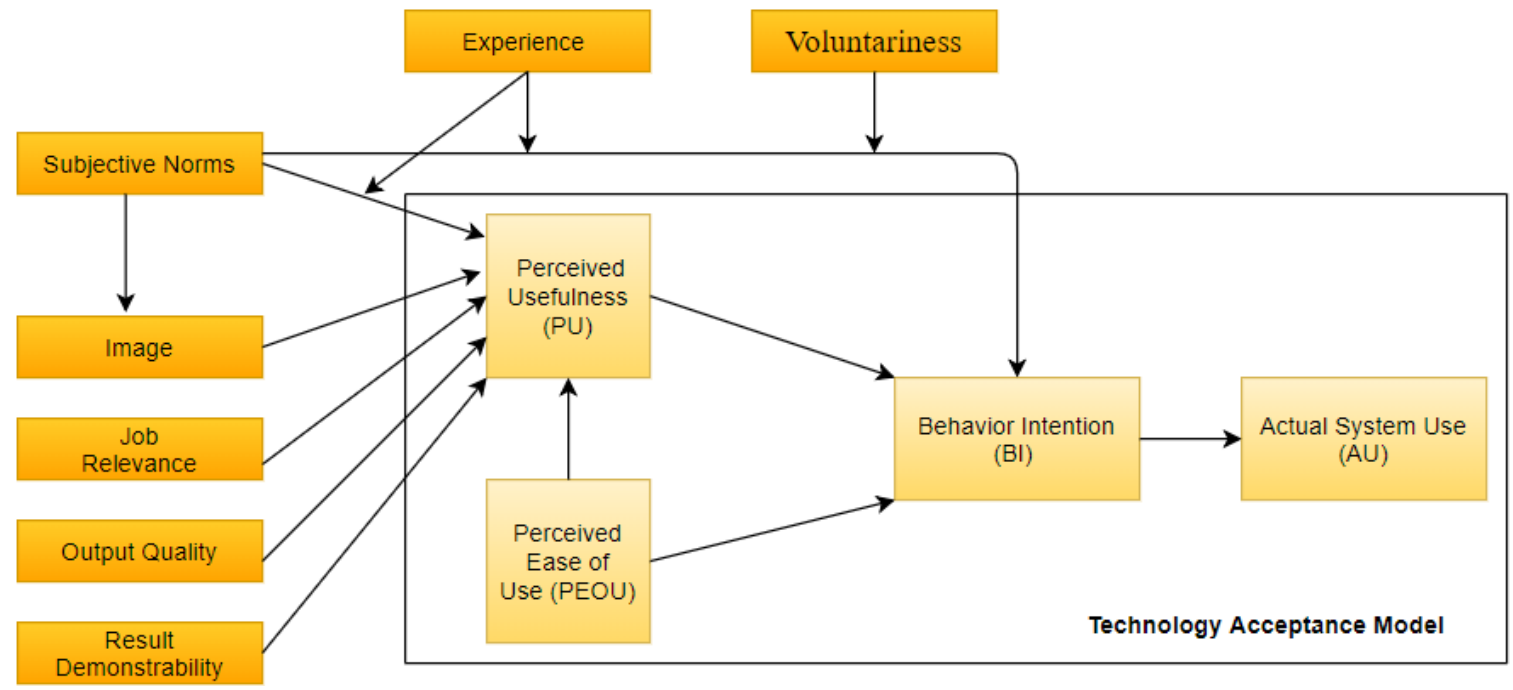

Figure 2. TAM 2 Source [15]

\subsection{TAM 2}

Venkatesh and Davis [15] expanded TAM to clarify the determining factors of perceived usefulness. The expanded demonstrate, known as the TAM2 (as illustrated in Figure 2), contains social influence processing variables (subjective norms, image, as well as voluntariness), cognitive instrumental processing variables (perceived ease of use, result demonstrability, output quality, job relevance). Table 2 shows the constructs of perceived usefulness in the TAM2
Venkatesh and Davis [15] performed longitudinal research to explore the suggested model on 156 employees in four companies who utilize four systems, where the use of two frameworks was optional, and the use of the other two frameworks was compulsory. The consequences confirmed the accomplishment of the suggested model is either chosen or compulsory use, where subjective norms do not affect voluntary environments. Moreover, the results of subjective norms on perceived usefulness, along with behavioral intention, tend to be reduced when the experience is expanded. 
Table 3. The Constructs of Perceived Ease of Use in the TAM 3

\begin{tabular}{|c|c|l|}
\hline Constructs & Literature support & \multicolumn{1}{|c|}{ Definition } \\
\hline Computer Anxiety & {$[8,26,45,46]$} & $\begin{array}{l}\text { The concern of utilizes the computer or concern of the potential of utilizing a } \\
\text { computer [47]. }\end{array}$ \\
\hline Perceived enjoyment & {$[48,49,50,51]$} & $\begin{array}{l}\text { Define as the level to which "the activity of applying a particular framework } \\
\text { considered to be interesting in its own right, regardless of the consequences" } \\
{[44] .}\end{array}$ \\
\hline Computer self-efficacy & {$[26,45,53 ; 54]$} & $\begin{array}{l}\text { Describe as the level to which persons believe they can achieve a particular } \\
\text { work utilizing the computer [52]. }\end{array}$ \\
\hline Computer playfulness & {$[55,56,57,58]$} & The fundamental inspiration to cooperate with the new framework [8]. \\
\hline Objective Usability & {$[5,44,59,60]$} & $\begin{array}{l}\text { The technology-based comparison regarding the actual, instead of user } \\
\text { perception, effort } \\
\text { that is compulsory to achieve specific tasks [44]. }\end{array}$ \\
\hline Perception of external control & {$[44,60,61,62]$} & $\begin{array}{l}\text { The level to which a person supposes that organizational assets are obtainable } \\
\text { to ease the system use [7]. }\end{array}$ \\
\hline
\end{tabular}

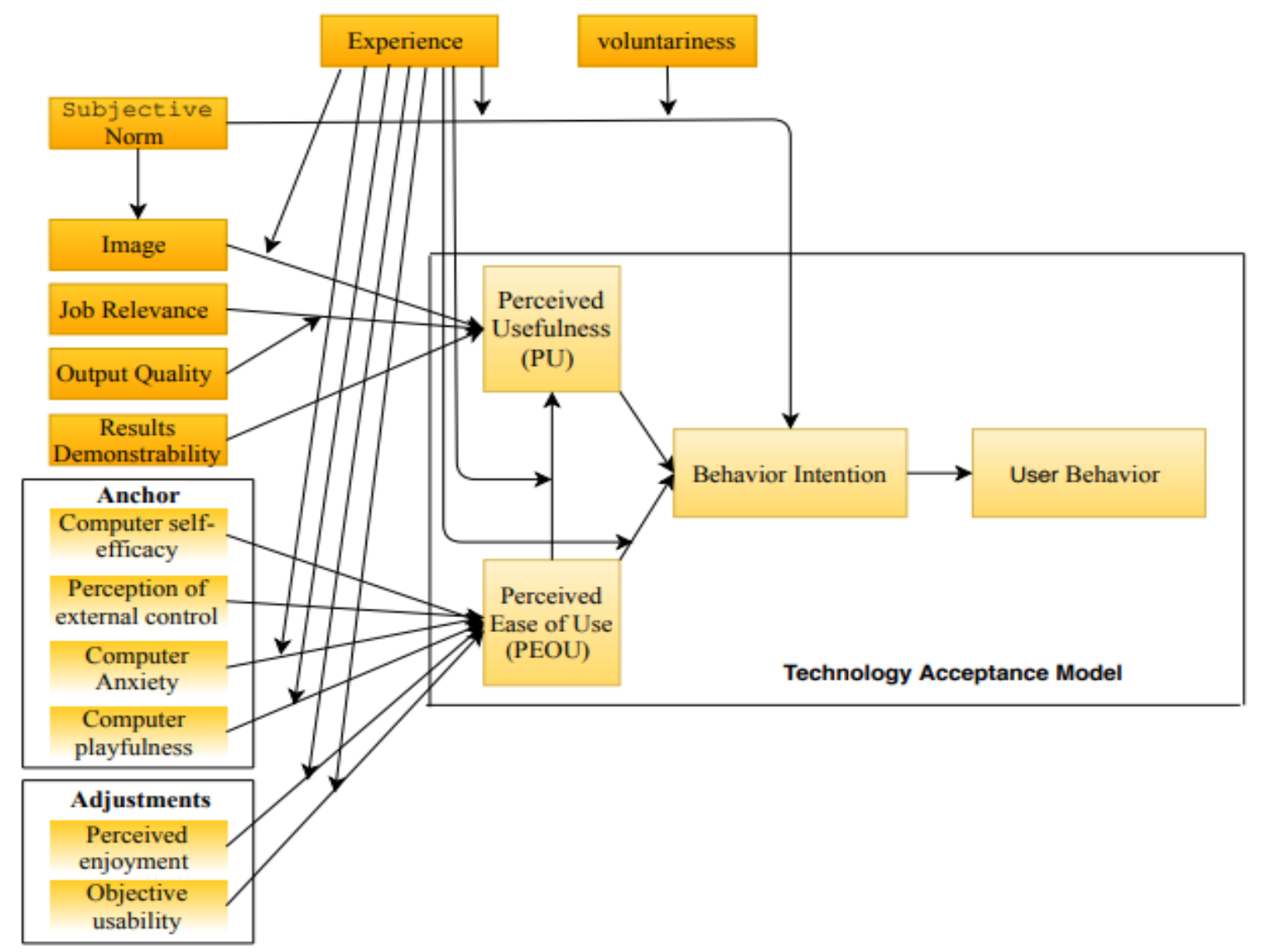

Figure 3. TAM 3 Source[8]

\subsection{TAM3}

The foremost later modification, the TAM generated an innovative model, described as the TAM3. The main participants of the TAM3 are addressing the key factors of perceived usefulness in addition to perceived ease of use [8]; as a result, the TAM3 was born from the integration of the TAM2 [15] with the paradigm of perceived ease of use determinants [44]. Figure (3) shows the constructs of the TAM3.

Venkatesh and Davis [15] assumed that perceived usefulness impacted by job relevance, output quality, image, perceived ease of use, results demonstrability, along with subjective norms. Output quality, experience, in addition to voluntariness, are categorized as moderators.

On the other side of the model, [8] assumed that perceived ease of use is impacted by what they call anchors and adjustments. Table (3)contains the declarations of the factors of perceived ease of use. These constructs were called 'anchors' for the reason that when the facts about the system's ease of use are deficient, persons tend to depend on general information (anchor) to perceive the system's ease of use. Venkatesh [44] theorized that the anchors, associated with computers and their use, drive people's preliminary opinion about the system's ease of use.

The four anchors that influence perceived ease of use are 
computer playfulness, perceptions of external control, computer self-efficacy, and computer anxiety $[8,44]$. The effect of computer playfulness along with computer anxiety on perceived ease of use is often reduced when an experience is increased; in contrast, the consequence of perceptions of external control and computer self-efficacy on perceived ease of use is often enhanced when an experience is increased [8,44]. However, the individual's attitude will be adjusted after gaining experience with the system, although still depends upon the primary anchors. Additionally, Venkatesh [44] theorized that the consequence of the adjustments, objective usability, and perceived enjoyment on perceived ease of use would be more significant when more experience has been achieved.

\section{Technology Acceptance Model' Concepts, Contribution, and Limitation}

TAM has been extensively criticized, even with its numerous utilizes. Critical comments of TAM as a "hypothesis" contain incomplete descriptive and analytical power and lack of practical value [63]. Separate tries by many scientists to develop TAM to adjust it to the energetic IT contexts have led to a "state of hypothetical confusion and uncertainty" [64]. Table (4) shows Technology acceptance Models and discussing their features, contributions, and the limits of each version of this theory.

Table 4. How TAMs concepts, contribution, and limitation

\begin{tabular}{|c|c|c|c|c|}
\hline TAM & Developed by & Concept & Contribution & Limitation \\
\hline TAM1 & Davis et al. [5] & $\begin{array}{l}\text { TAM utilizes the theory of } \\
\text { reasoned action as a conceptual } \\
\text { basis to link actual system usage } \\
\text { behavior, perceived ease of use, } \\
\text { users' intentions, attitudes, as well } \\
\text { as perceived Usefulness. TAM } \\
\text { hypothesized that perceived ease } \\
\text { of use plus perceived usefulness } \\
\text { act as a mediator for the impact of } \\
\text { external factors. }\end{array}$ & $\begin{array}{l}\text { Initial theory devoted to IS, due } \\
\text { to its great number of quotations, } \\
\text { its permanence [67], or due to it } \\
\text { was the earliest technology } \\
\text { acceptance model considering } \\
\text { wide-ranging of experimental } \\
\text { support [68]. }\end{array}$ & $\begin{array}{l}\text { 1) inadequacy emphasis of } \\
\text { external factors: comprising } \\
\text { variables as an example prior } \\
\text { experience, facilitating } \\
\text { conditions, or perceived } \\
\text { enjoyment. 2) poor variance in } \\
\text { investigative studies[65,66] }\end{array}$ \\
\hline TAM2 & $\begin{array}{c}\text { (Venkatesh and } \\
\text { Davis, [15] }\end{array}$ & $\begin{array}{l}\text { The social influence processes } \\
\text { with the cognitive instrumental } \\
\text { procedures are incorporated into } \\
\text { this model. The Couple } \\
\text { procedures were measured to be } \\
\text { critical to examine user adoption }\end{array}$ & $\begin{array}{l}\text { The developer search for the } \\
\text { factors of perceived usefulness, } \\
\text { initial, to enhance design the } \\
\text { institutional involvement made } \\
\text { upon acceptance of the user and } \\
\text { then to anticipation the utilize of } \\
\text { innovations when they are } \\
\text { provided in a professional } \\
\text { situation". This model comprises } \\
\text { more factors and particularly the } \\
\text { factors that impact the perceived } \\
\text { usefulness. }\end{array}$ & $\begin{array}{l}\text { The TAM } 2 \text { may be criticized } \\
\text { as being a non-complete } \\
\text { model because it does not } \\
\text { determine the factors that } \\
\text { impact the perceived ease of } \\
\text { use. }\end{array}$ \\
\hline TAM3 & $\begin{array}{c}\text { Venkatesh et al. } \\
{[8]}\end{array}$ & $\begin{array}{l}\text { The developer proposes that } \\
\text { experience as a mediator to the } \\
\text { relationships among perceived } \\
\text { ease of use with behavioral } \\
\text { intention usefulness, computer } \\
\text { anxiety with perceived ease of } \\
\text { use, as well as perceived ease of } \\
\text { use with perceived. TAM3 } \\
\text { (Venkatesh and Bala, [8] are } \\
\text { derived from a theoretical } \\
\text { framework composed of four } \\
\text { groups. Each of the four groups: } \\
\text { individual difference, system } \\
\text { distinctiveness, } \\
\text { influence, as well as facilitating } \\
\text { conditions, made up of their } \\
\text { factors based on the two critical } \\
\text { elements of perceived usefulness } \\
\text { as well as perceived ease of use } \\
\text { [70]. }\end{array}$ & $\begin{array}{l}\text { TAM3 offered a full nomological } \\
\text { network of the factors of users' } \\
\text { Information Technology System } \\
\text { acceptance [8] TAM3 has made } \\
\text { considerable hypothetical, } \\
\text { contributed by identifying the } \\
\text { factors of perceived usefulness in } \\
\text { addition to perceived ease of use } \\
\text { (Fig 3). It has included elements } \\
\text { of context, content, process, and } \\
\text { individual differences [8] }\end{array}$ & $\begin{array}{l}\text { In accordance with the } \\
\text { research consequences of } \\
\text { [69], the complex models do } \\
\text { not inevitably have better } \\
\text { clarification ability. } \\
\text { Therefore, since the TAM3 } \\
\text { provides an extremely long } \\
\text { and complicated model, it } \\
\text { represents a constraint that } \\
\text { could prevent its employ. }\end{array}$ \\
\hline
\end{tabular}




\section{Literature Review}

\section{Technology Acceptance and Adoption in Education}

The fast growth of information technologies has been recognized as brought a large revolutionize in education organizations. Web-based e-learning (electronic learning) as a substitute education form has developed an advanced learning context and granted learners with an excellent chance to cooperate with others. With e-learning systems, internet distribution of instruction and computer-based resources of knowledge can be achieved without the restriction of space and time. Sánchez and Hueros [71] designated that e-learning contexts assisted educational systems to cross spatial and sequential difficulties, fostered significant learning, and offer convenience in addition to flexibility. Yoon and Kim [72] recommended that perceived convenience would be measured as a vital factor of the users' recognition as well as utilize of information technology.

Recently, With the expansion of information communication technology, a variety of manuscripts have been issued on the environment of application of TAM in the academic community, E.g., :[72,74,75,76,77]. numerous investigation have utilized TAM to inspect learners' motivation to adopt e-learning platforms E.g.:[78, $79,80,81 ; 82 ; 83,84]$, or to expect learners' intentions to apply web-based learning society [85].The consequences of these studies indicated that TAM could professionally predict and clarify users' adoption of information technology.

The intention of a user towards employing an e-learning technology was essentially explained by applies or expanding the TAM investigated model with other related constructs. While, for instance, [86] have experienced the application of the original TAM in the educational field, [87] and [88] have utilized the extended TAM model.

Diverse acceptance researches in the field have been examining TAM's suitability for various learning technologies, similar to mobile learning [89], Personal Learning Environments (PLEs) [90], Learning Management Systems (LMSs) in general [91] in addition to open-source LMS Moodle [71] and commercial LMS Blackboard [92] in particular.
Dasgupta, Granger, and McGarry [93] evaluated the adoption of courseware management technology as an e-collaboration tool by bachelor's learners. They concluded that the year of a user in school was an essential factor in the utilization. Moreover, Selim[94] examined TAM through web-based learning. He suggested the course website acceptance model (CWAM) and examined the associations between perceived ease of use, perceived usefulness, plus intention to use between learners of the university. The outcome of the study stated that the model accommodates the collected data.

Furthermore, [94] stated that the ease of use and usefulness are essential variables of the recognition and utilization of the course website. With the incorporation of the motivational hypothesis with TAM, [95] examined students of university acceptance behavior towards an Internet-based learning medium (ILM) presenting TAM. [94] incorporated perceived enjoyment as a primary aspect besides perceived ease of use in addition to perceived usefulness. The outcome pointed out that perceived usefulness, in addition to perceived enjoyment, influenced equally learners' intention to use as well as an attitude toward ILM. Yet, perceived ease of use was concluded to be not linked to attitude.

Van Raaij and Schepers [84] investigated the adoption and utilization of the online learning context in China. The outcome pointed out that perceived usefulness has a direct consequence on the employ of virtual learning environments (VLE). Subjective norms, as well as perceived ease of use, had an indirect impact on perceived usefulness. Also, it confirmed that perceived ease of use had been directly impacted by new factors associated with personal characteristics such as sensations of concern about utilizing the computer. [96] investigated the level to which TAM was capable to clarify faculty adoption of web-based education sufficiently. Outcome specify that perceived usefulness is a good indicator of school adoption; but, perceived ease of use provides slight supplementary predictive power beyond that participated by perceived usefulness of web-based learning technology.

Table 5 presents the latest studies that adopt TAM in the education field for different platforms in different countries besides the sample size and conclusion for each study. 
Table 5. Latest studies that show TAM adoption in education

\begin{tabular}{|c|c|c|c|c|c|c|}
\hline Num & Year & Platform & User Type & Sample Size & Country & study \\
\hline$[97]$ & 2012 & $\begin{array}{l}\text { E-Learning system } \\
\text { (Moodle platform ) }\end{array}$ & students & 162 & Spain & $\begin{array}{l}\text { utilize TAM for illumination or } \\
\text { predicting students of university' } \\
\text { adoption of the Moodle platform }\end{array}$ \\
\hline$[98]$ & 2009 & statistical software & student & 207 & $\begin{array}{l}\text { United } \\
\text { States }\end{array}$ & $\begin{array}{l}\text { conducted an experimental study to } \\
\text { analyze the acceptance of statistical } \\
\text { soft-ware between internet-based MBA } \\
\text { students }\end{array}$ \\
\hline$[99]$ & 2016 & Blended e-learning & student & 396 & Vietnam & $\begin{array}{l}\text { the aspire of this research is to inspect the } \\
\text { learner's attitude in the environment of } \\
\text { e-learning; three factors in the TAM } \\
\text { were chosen for the hypothetical model: } \\
\text { Attitude, Perceived Ease of Use, in } \\
\text { addition to perceived usefulness." }\end{array}$ \\
\hline [100] & 2015 & E-Learning system & $\begin{array}{l}\text { Students \& } \\
\text { teachers }\end{array}$ & 156 & Australia & $\begin{array}{l}\text { State that utilizes of E-Learning system } \\
\text { in the education area is serving as new } \\
\text { forms to offer learning content to } \\
\text { everyone without the constraint of time } \\
\text { and place. accurate utilization of } \\
\text { Information Technology items can } \\
\text { improve users' adoption for successful } \\
\text { E-Learning }\end{array}$ \\
\hline [101] & 2010 & $\begin{array}{l}\text { E-learning system } \\
\text { (Wikis) }\end{array}$ & students & 126 & $\begin{array}{l}\text { United } \\
\text { States }\end{array}$ & $\begin{array}{l}\text { The study noted that wiki use intention, } \\
\text { perceived usefulness, perceived ease of } \\
\text { use, in addition to wiki self-efficacy have } \\
\text { a direct plus considerable indirect impact } \\
\text { on wiki utilization in the classroom. }\end{array}$ \\
\hline [102] & 2007 & $\begin{array}{l}\text { E-Learning system } \\
\text { (Web Course Tools- } \\
\text { WebCT) }\end{array}$ & Students & 1,263 & Hong Kong & $\begin{array}{l}\text { examined the variables that impact } \\
\text { WebCT utilization in higher educational } \\
\text { institutions in applying the TAM model }\end{array}$ \\
\hline [103] & 2011 & $\begin{array}{l}\text { E-learning system } \\
\text { (e-government } \\
\text { learning) }\end{array}$ & students & 307 & Taiwan & $\begin{array}{l}\text { carried out that perceived enjoyment has } \\
\text { a positive impact on perceived ease of } \\
\text { use for adopting recognition of } \\
\text { government information system }\end{array}$ \\
\hline$[91]$ & 2014 & $\begin{array}{l}\text { Learning management } \\
\text { systems }\end{array}$ & $\begin{array}{l}\text { Faculty } \\
\text { members }\end{array}$ & 59 & $\begin{array}{l}\text { Saudi } \\
\text { Arabia }\end{array}$ & $\begin{array}{l}\text { encourages that TAM has been assumed } \\
\text { and experienced as a positive framework } \\
\text { in the field of information science and } \\
\text { Learning Management Systems }\end{array}$ \\
\hline [104] & 2018 & Moodle environment & students & 89 & Hungary & $\begin{array}{l}\text { The study was to inspect the influential } \\
\text { factors of students' video utilization and } \\
\text { their learning fulfillment relating to the } \\
\text { corresponding application of educational } \\
\text { videos, available in a Moodle context in } \\
\text { a Business Mathematics Course. }\end{array}$ \\
\hline [105] & 2019 & $\begin{array}{c}\text { E-learning } \\
\text { technology/tools } \\
\text { (Social Networking) }\end{array}$ & $\begin{array}{l}\text { teachers and } \\
\text { administrative } \\
\text { employees }\end{array}$ & 523 & Iran & $\begin{array}{l}\text { This research deal with examining the } \\
\text { adoption of social networks by those } \\
\text { concerned about the educational system } \\
\text { of Ahwaz }\end{array}$ \\
\hline [106] & 2020 & $\begin{array}{l}\text { E-learning } \\
\text { technology/tools } \\
\text { (Mobile) }\end{array}$ & students & 71 & China & $\begin{array}{l}\text { This study tries to conclude the } \\
\text { recognition of Rain Classroom based on } \\
\text { constructs of UTAUT and to recognize } \\
\text { the efficiency of Rain Classroom based } \\
\text { on learning results in linguistics courses. }\end{array}$ \\
\hline [107] & 2008 & $\begin{array}{l}\text { E-learning } \\
\text { technology/tool. } \\
\text { (E-collaboration) }\end{array}$ & students & 225 & Spain & $\begin{array}{l}\text { This paper has two primary goals. The } \\
\text { first one is to analyze the utilize of } \\
\text { e-collaboration technologies between } \\
\text { management students experimentally. } \\
\text { The second goal is to analyze the factors } \\
\text { that efficiently influence that utilization. }\end{array}$ \\
\hline
\end{tabular}

\section{Conclusions}

Last few years, institutes of higher education investment in incorporate web-based innovations in the classes within the context of the learning when compared with studies on another information technology users' behavior towards this type of system, nevertheless, have not been evaluated and understood comprehensively. (TAM) in general, 
regarded as a remarkable hypothesis as a consequence of the escalating volume of related researches over the last few years. This theory has applied to diverse sectors, different conditions, or fundamental determinants. TAM plays a considerable role in the information systems field, as Davis developed this hypothesis in (1989). The purpose of this study was to present the progress of TAM and show the restrictions of the prior version of this theory, furthermore, to study the technology acceptance and adoption in education to have more knowledge about individual behaviors in the multimedia learning context. A detailed consideration of technology acceptance research in the education area published in quality journals was offered. From the study of these studies, many vital patterns in the current research were found. It was found that the more significant part of the acceptance studies in the education area has been on e-learning.

As described, acceptance previously varied based on types of users; as a result, acceptance research on user type lecturers or teachers is essential, and future studies necessitate to be done. This comprehensive review of adopting TAM in education can be beneficial to future researchers as they can quickly recognize the variables, causal relationships, user types studied, and the education area in which technology acceptance has been considered. The information gathered in this study can be used for future technology acceptance studies in the education domain.

\section{REFERENCES}

[1] Rossmann, C. (2010) Theory of reasoned action-theory of planned behavior: Nomos Verlagsgesellschaft mbH \& Co. KG.

[2] Fishbein, M., \&Ajzen, I. (1975). Belief, attitude, intention and behavior: An introduction to theory and research. Reading, MA: Addison-Wesley.

[3] Mathieson, K. (1991). Predicting User Intentions: Comparing the Technology Acceptance Model with the Theory of Planned Behavior. Information Systems Research, 2(3), 173-191.

[4] Ajzen, I. (1991). The theory of planned behavior. Organizational behavior and human decision processes, 50(2), 179-211.

[5] Davis, F. D., Bagozzi, R. P., \& Warshaw, P. R. (1989). User acceptance of computer technology: a comparison of two theoretical models. Management science, 35(8), 982-1003.

[6] Davis, F. D. (1989). Perceived usefulness, perceived ease of use, and user acceptance of information technology. MIS quarterly, 319-340.

[7] Venkatesh, V., Morris, M. G., Davis, G. B., \& Davis, F. D. (2003). User acceptance of information technology: Toward a unified view. MIS quarterly, 425-478.

[8] Venkatesh, V., \& Bala, H. (2008). Technology Acceptance
Model 3and A Research Agenda On Interventions. Decision Sciences, 39(2), 273-315.

[9] Cooper, \& Juett, R. (1998). A multidimensional approach to the adoption of innovation. Management Decision, 36(8), 493-502.

[10] Arts, J. W., Frambach, R. T., \&Bijmolt, T. H. (2011). Generalizations on consumer innovation adoption: A meta-analysis on drivers of intention and behavior. International Journal of Research in Marketing, 28(2), 134-144.

[11] Kulviwat, S., Ii, G. C. B., \& Al-Shuridah, O. (2009). The role of social influence on adoption of high tech innovations: The moderating effect of public/private consumption. Journal of Business Research, 62(7), 706-712

[12] Teo, T., \& Zhou, M. (2017). The influence of teachers' conceptions of teaching and learning on their technology acceptance. Interactive Learning Environments, 25(1-4), 513-527.

[13] Nath, R., Bhal, K. T., \& Kapoor, G. T. (2013). Factors influencing IT Adoption by Bank Employees: An Extended TAM Approach. Vikalpa the Journal for Decision Makers, 38(4), 83-96.

[14] Szajna, B. (1996). Empirical evaluation of the revised technology acceptance model. Management science, 42(1), 85-92.

[15] Venkatesh, V., \& Davis, F. D. (2000). A theoretical extension of the technology acceptance model: Four longitudinal field studies. Management science, 46(2), 186-204.

[16] Robles-Gómez, A., Ros, S., Hernández, R., Tobarra, L., Caminero, A. C., \&Agudo, J. M. (2015). User Acceptance of a Proposed Self-Evaluation and Continuous Assessment System. Journal of Educational Technology \& Society, $18(2)$.

[17] Chakraborty, S.,\& Mirta,D. (2018). A study of Consumer Adoption of Digital Wallets in India. International Journal on Consumer Relation, 6(1), 38.

[18] Davis, F. D. (1986). The technology acceptance model for empirically testing new end-user information systems: theory and results [Ph.D. thesis]. Ph.d.dissertation Massachusetts Institute of Technology.

[19] Surendran, P. (2012). Technology Acceptance Model: A Survey of Literature. International Journal of Business \& Social Research, 2.

[20] Kashi, K., \& Zheng, C. (2013). Extending Technology Acceptance Model to the E - recruitment Context in I ran. International Journal of Selection and Assessment, 21(1), 121-129.

[21] Shroff, R. H., Deneen, C. C., \& Ng, E. M. (2011). Analysis of the technology acceptance model in examining students' behavioural intention to use an e-portfolio system. Australasian Journal of Educational Technology, 27(4).

[22] Fathema, N., Shannon, D., \& Ross, M. (2015). Expanding the Technology Acceptance Model (TAM) to examine faculty use of Learning Management Systems (LMSs) in higher education institutions. Journal of Online Learning \& Teaching, 11(2). 
[23] Ghosh, B. (2016). Exploratory study of effects of elearning system acceptance on learning outcomes. Journal of Information Systems Applied Research, 9(2), 13.

[24] Bourgonjon, J., De Grove, F., De Smet, C., Van Looy, J., Soetaert, R., \& Valcke, M. (2013). Acceptance of game-based learning by secondary school teachers. Computers \& Education, 67, 21-35.

[25] Schepers, J., \& Wetzels, M. (2007). A meta-analysis of the technology acceptance model: Investigating subjective norm and moderation effects. Information \& management, 44(1), 90-103.

[26] Compeau, D., Higgins, C. A., \& Huff, S. (1999). Social cognitive theory and individual reactions to computing technology: A longitudinal study. MIS quarterly, 145-158.

[27] Agarwal, R., \& Stair, S. R. M. (2000). Research Report: The Evolving Relationship Between General and Specific Computer Self-Efficacy-An Empirical Assessment. Information Systems Research, 11(4), 418-430.

[28] Guimaraes, T., \& Igbaria, M. (1997). Assessing user computing effectiveness: An integrated model. Journal of Organizational and End User Computing (JOEUC), 9(2), 3-15.

[29] Taylor, S., \& Todd, P. A. (1995). Understanding information technology usage: A test of competing models. Information systems research, 6(2), 144-176.

[30] Gefen, D., Karahanna, E., \& Straub, D. W. (2003). Trust and TAM in online shopping: An integrated model. MIS quarterly, 27(1), 51-90.

[31] Hu, P.-H., Chau, P. Y., Chan, Y., \& Kwok, J. (2001). Investigating technology implementation in A neurosurgical teleconsultation program: A case study in Hong Kong. Paper presented at the Proceedings of the 34th Annual Hawaii International Conference on System Sciences.

[32] Hu, P. J., Chau, P. Y., Sheng, O. R. L., \& Tam, K. Y. (1999). Examining the technology acceptance model using physician acceptance of telemedicine technology. Journal of management information systems, 16(2), 91-112.

[33] Kocaleva, M., Stojanovic, I., \& Zdravev, Z. (2015). Model of e-learning acceptance and use for teaching staff in Higher Education Institutions. International Journal of Modern Education and Computer Science (IJMECS), 7(4), 23-31.

[34] Thompson, R. L., Higgins, C. A., \& Howell, J. M. (1991). Personal computing: toward a conceptual model of utilization. MIS quarterly, 125-143.

[35] Moore, G. C., \& Benbasat, I. (1991). Development of an instrument to measure the perceptions of adopting an information technology innovation. Information Systems Research, 2(3), 192-222.

[36] ROGERS, \& E.M. (1995). Diffusion of innovation. 4th ed: Free Press.

[37] Chen, W. S., \& Yao, A. Y. T. (2016). An empirical evaluation of critical factors influencing learner satisfaction in blended learning: A pilot study. Universal Journal of Educational Research, 4(7), 1667-1671.

[38] Kim, S., \& Garrison, G. (2009). Investigating mobile wireless technology adoption: An extension of the technology acceptance model. Information Systems Frontiers, 11(3), 323-333.

[39] Alambaigi, A., \&Ahangari, I. (2016). Technology Acceptance Model (TAM) As a Predictor Model for Explaining Agricultural Experts Behavior in Acceptance of ICT. International Journal of Agricultural Management and Development (IJAMAD), 6(1047-2017-1663), 235-247.

[40] Chismar, W. G., \& Wiley-Patton, S. (2002). Test of the technology acceptance model for the internet in pediatrics. Paper presented at the Proceedings of the AMIA Symposium.

[41] Al-Gahtani, S. S. (2016). Empirical investigation of e-learning acceptance and assimilation: A structural equation model. Applied Computing and Informatics, 12(1), $27-50$.

[42] Rouibah, K. (2009). Intention to use Camera Mobile Phone before E-Shopping in the Arab world: Test of the Applicability of TAM 2. Paper presented at the IADIS International Conference Information Systems.

[43] Moreno, V., Cavazotte, F., \&Alves, I. (2017). Explaining university students' effective use of e - learning platforms. British Journal of educational technology, 48(4), 995-1009.

[44] Venkatesh, V. (2000). Determinants of perceived ease of use: Integrating control, intrinsic motivation, and emotion into the technology acceptance model. Information Systems Research, 11(4), 342-365.

[45] Igbaria, M., Parasuraman, S., \& Baroudi, J. J. (1996). A motivational model of microcomputer usage. Journal of management information systems, 13(1), 127-143.

[46] Bandura, A. (1986). The explanatory and predictive scope of self-efficacy theory. Journal of social and clinical psychology, 4(3), 359-373.

[47] Chua, S. L., Chen, D.-T., \& Wong, A. F. (1999). Computer anxiety and its correlates: a meta-analysis. Computers in human behavior, 15(5), 609-623.

[48] Park, Y., Son, H., \& Kim, C. (2012). Investigating the determinants of construction professionals' acceptance of web-based training: Ah extension of the technology acceptance model. Automation in Construction, 22(Mar.), p.377-386.

[49] Al-Aulamie, A., Mansour, A., Daly, H., \&Adjei, O. (2012). The effect of interinsic motivation on learners' behavioural intention to use e-learning systems. Paper presented at the 2012 International Conference on information technology based higher education and training (ITHET).

[50] Chen, Y. C., Lin, Y. C., Yeh, R. C., \& Lou, S. J. (2013). EXAMINING FACTORS AFFECTING COLLEGE STUDENTS' INTENTION TO USE WEB-BASED INSTRUCTION SYSTEMS: TOWARDS AN INTEGRATED MODEL. Turkish Online Journal of Educational Technology Tojet, 12(2), 111-121.

[51] Zare, H., \& Yazdanparast, S. (2013). The causal Model of effective factors on intention to use of information technology among payamnoor and traditional universities students. Life Science Journal, 10(2), 46-50.

[52] Compeau, D. R., \& Higgins, C. A. (1995). Computer self-efficacy: Development of a measure and initial test. MIS 
quarterly, 189-211.

[53] Shen, J., \& Eder, L. (2009). Determining factors in the acceptance of social shopping websites. Paper presented at the Americas Conference on Information Systems.

[54] Strong, D. M., Dishaw, M. T., \& Bandy, D. B. (2006). Extending task technology fit with computer self-efficacy. ACM SIGMIS Database: the DATABASE for Advances in Information Systems, 37(2-3), 96-107.

[55] Calisir, F., AltinGumussoy, C., Bayraktaroglu, A. E., \&Karaali, D. (2014). Predicting the intention to use a web based learning system: Perceived content quality, anxiety, perceived system quality, image, and the technology acceptance model. Human Factors and Ergonomics in Manufacturing \& Service Industries, 24(5), 515-531.

[56] Capece, G., \&Campisi, D. (2013). User satisfaction affecting the acceptance of an e-learning platform as a mean for the development of the human capital. Behaviour\& Information Technology, 32(4), 335-343.

[57] Chang, C.-T., Hajiyev, J., \& Su, C.-R. (2017). Examining the students' behavioral intention to use e-learning in Azerbaijan? The general extended technology acceptance model for e-learning approach. Computers \& Education, 111, 128-143.

[58] Cheng, Y. M. (2014). Extending the expectation-confirmation model with quality and flow to explore nurses' continued blended e-learning intention. Information Technology \& People, 27(3), 230-258.

[59] Venkatesh, V., \& Davis, F. D. (1996). A Model of the Antecedents of Perceived Ease of Use: Development and Test. Decision Sciences, 27(3), 451-481.

[60] Al-Gahtani, S. S. (2016). Empirical investigation of e-learning acceptance and assimilation: A structural equation model. Applied Computing and Informatics, 12(1), $27-50$.

[61] Arenas-Gaitán, J., Rondan-Cataluña, F. J., \& Ramirez-Correa, P. E. (2010). Gender influence in perception and adoption of e-learning platforms. Paper presented at the Proceedings of the 9th WSEAS international conference on Data networks, communications, computers.

[62] Ramírez-Correa, P. E., Arenas-Gaitán, J., \&Rondán-Cataluña, F. J. (2015). Gender and acceptance of e-learning: a multi-group analysis based on a structural equation model among college students in Chile and Spain. PloS one, 10(10).

[63] Chuttur, M. Y. (2009). Overview of the technology acceptance model: Origins, developments and future directions. Working Papers on Information Systems, 9(37), 9-37.

[64] Benbasat, I., \&Barki, H. (2007). Quo vadis TAM? Journal of the association for information systems, 8(4), 7.

[65] García, Á. H. (2008). Desarrollo de unmodelounificado de adopción del comercioelectrónico entre empresas y consumidores finales. Aplicación al mercadoespañol. ETSI Telecomunicación. Madrid: UPM.

[66] Legris, P., Ingham, J., \& Collerette, P. (2003). Why do people use information technology? A critical review of the technology acceptance model. Information \& management, 40(3), 191-204.

[67] Jawadi, N. (2014). Facteurs-clés de l'adoption des systèmesd'informationdans la grande distribution alimentaire: uneapprocheparl'UTAUT. Paper presented at the 17ème Colloque de l'Association Information et Management (AIM), Bordeaux.

[68] Amoako-Gyampah, K., \& Salam, A. F. (2004). An extension of the technology acceptance model in an ERP implementation environment. Information \& management, 41(6), 731-745.

[69] Jen, M. H., Jones, K., \& Johnston, R. (2009). Global variations in health: evaluating Wilkinson's income inequality hypothesis using the World Values Survey. Social science \& medicine, 68(4), 643-653.

[70] Howard, N. L., Marshall, P., \& Swatman, P. A. (2010). Reconceptualising motivation in adoption and acceptance research: Back to basics. Paper presented at the ACIS.

[71] Sánchez, R. A., \& Hueros, A. D. (2010). Motivational factors that influence the acceptance of Moodle using TAM. Computers in human behavior, 26(6), 1632-1640.

[72] Yoon, C., \& Kim, S. (2007). Convenience and TAM in a ubiquitous computing environment: The case of wireless LAN. Electronic Commerce Research and Applications, 6(1), 102-112.

[73] Teo, T. (2009a). A case for using structural equation modelling (SEM) in educational technology research. British Journal of educational technology, 41(5), E89-E91.

[74] Teo, T. (2009b). Modelling Technology Acceptance In Education: A Study Of Pre-service Teachers. Computers \& Education, 52(2), p.302-312.

[75] Teo, T. (2010a). An Empirical Study to Validate the Technology Acceptance Model (TAM) in Explaining the Intention to Use Technology among Educational Users. International journal of information and communication technology education: an official publication of the Information Resources Management Association, 6(4), 1-12.

[76] Teo, T. (2010b). Examining the influence of subjective norm and facilitating conditions on the intention to use technology among pre-service teachers: a structural equation modeling of an extended technology acceptance model. Asia Pacific Education Review, 11(2), 253-262.

[77] Teo, T. (2010c). A path analysis of pre-service teachers' attitudes to computer use: applying and extending the technology acceptance model in an educational context. Interactive Learning Environments, 18(1), 65-79.

[78] Al-Adwan, A., Al-Adwan, A., \& Smedley, J. (2013). Exploring students acceptance of e-learning using Technology Acceptance Model in Jordanian universities. International Journal of Education and Development using ICT, 9(2).

[79] Tabak, F., \& Nguyen, N. T. (2013). Technology acceptance and performance in online learning environments: Impact of self-regulation. Technology, 9(1), 116-130.

[80] Liaw, S.-S., Huang, H.-M., \& Chen, G.-D. (2007). Surveying instructor and learner attitudes toward e-learning. 
Computers \& Education, 49(4), 1066-1080.

[81] Ong, C.-S., \& Lai, J.-Y. (2006). Gender differences in perceptions and relationships among dominants of e-learning acceptance. Computers in human behavior, 22(5), 816-829.

[82] Ong, C.-S., Lai, J.-Y., \& Wang, Y.-S. (2004). Factors affecting engineers' acceptance of asynchronous e-learning systems in high-tech companies. Information \& management, 41(6), 795-804.

[83] Šumak, B., Heričko, M., Pušnik, M., \& Polančič, G. (2011). Factors affecting acceptance and use of Moodle: An empirical study based on TAM. Informatica, 35(1).

[84] Van Raaij, E. M., \& Schepers, J. J. (2008). The acceptance and use of a virtual learning environment in China. Computers \& Education, 50(3), 838-852.

[85] Liu, I.-F., Chen, M. C., Sun, Y. S., Wible, D., \& Kuo, C.-H. (2010). Extending the TAM model to explore the factors that affect Intention to Use an Online Learning Community. Computers \& Education, 54(2), 600-610.

[86] Farahat, T. (2012). Applying the technology acceptance model to online learning in the Egyptian universities. Procedia-Social and Behavioral Sciences, 64, 95-104.

[87] Zhang, S., Zhao, J., \& Tan, W. (2008). Extending TAM for online learning systems: An intrinsic motivation perspective. Tsinghua Science \& Technology, 13(3), 312-317.

[88] Cheung, R., \& Vogel, D. (2013). Predicting user acceptance of collaborative technologies: An extension of the technology acceptance model for e-learning. Computers \& Education, 63(apr.), 160-175.

[89] Sánchez-Prieto, J. C., Olmos-Migueláñez, S., \&García-Peñalvo, F. J. (2016). Informal tools in formal contexts: Development of a model to assess the acceptance of mobile technologies among teachers. Computers in human behavior, 55, 519-528.

[90] del Barrio-García, S., Arquero, J. L., \& Romero-Frías, E. (2015). Personal Learning Environments Acceptance Model: The Role of Need for Cognition, e-Learning Satisfaction and Students. Perceptions. Educational technology \& society, 18(3), 129-141.

[91] Alharbi, S., \& Drew, S. (2014). Using the technology acceptance model in understanding academics' behavioural intention to use learning management systems. International Journal of Advanced Computer Science and Applications, $5(1), 143-155$.

[92] Ibrahim, R., Leng, N., Yusoff, R., Samy, G., Masrom, S., \&Rizman, Z. (2017). E-learning acceptance based on technology acceptance model (TAM). Journal of Fundamental and Applied Sciences, 9(4S), 871-889.

[93] Subhasish, Dasgupta, Mary, GrangerNina, \& McGarry. (2002). User Acceptance of E-Collaboration Technology: An Extension of the Technology Acceptance Model. Group Decision \& Negotiation.

[94] Selim, H. M. (2003). An empirical investigation of student acceptance of course websites. Computers \& Education, 40(4), 343-360.

[95] Lee, M. K., Cheung, C. M., \& Chen, Z. (2005). Acceptance of Internet-based learning medium: the role of extrinsic and intrinsic motivation. Information \& management, 42(8), 1095-1104.

[96] Gibson, S. G., Harris, M. L., \& Colaric, S. M. (2008). Technology acceptance in an academic context: Faculty acceptance of online education. Journal of Education for Business, 83(6), 355-359.

[97] Escobar-Rodriguez, T., \& Monge-Lozano, P. (2012a). The acceptance of Moodle technology by business administration students. Computers \& Education, 58(4), 1085-1093.

[98] Hsu, M. K., Wang, S. W., \& Chiu, K. K. (2009). Computer attitude, statistics anxiety and self-efficacy on statistical software adoption behavior: An empirical study of online MBA learners. Computers in human behavior, 25(2), 412-420.

[99] Tran, K. N. N. (2016). The Adoption of Blended E-learning Technology in Vietnam using a Revision of the Technology Acceptance Model. Journal of Information Technology Education, 15.

[100] Wong, K.-T., Teo, T., \& Goh, P. S. C. (2015). Understanding the intention to use interactive whiteboards: model development and testing. Interactive Learning Environments, 23(6), 731-747.

[101] Liu, X. (2010). Empirical testing of a theoretical extension of the technology acceptance model: An exploratory study of educational wikis. Communication Education, 59(1), 52-69.

[102] Ngai, E. W., Poon, J., \& Chan, Y. H. (2007). Empirical examination of the adoption of WebCT using TAM. Computers \&Education, 48(2), 250-267.

[103] Shyu, S. H.-P., \& Huang, J.-H. (2011). Elucidating usage of e-government learning: A perspective of the extended technology acceptance model. Government Information Quarterly, 28(4), 491-502

[104] Nagy, J. T. (2018). Evaluation of online video usage and learning satisfaction: An extension of the technology acceptance model. International Review of Research in Open and Distributed Learning, 19(1).

[105] Hamdani, M. (2019). Technology Acceptance in the Use of Social Networks by Teachers and Employees of Education Offices in Ahwaz. Turkish Online Journal of Educational Technology-TOJET, 18(1), 105-117.

[106] Yu, Z., \& Yi, H. (2020). Acceptance and Effectiveness of Rain Classroom in Linguistics Classes. International Journal of Mobile and Blended Learning (IJMBL), 12(2), 77-90.

[107] Padilla-Meléndez, A., Garrido-Moreno, A., \& Del Aguila-Obra, A. R. (2008). Factors affecting e-collaboration technology use among management students. Computers \& Education, 51(2), 609-623. 